\title{
Study the impact of labor outsourcing on the financial performance of small and medium enterprises in Mekong Delta, Vietnam
}

\author{
Dinh Cong Thanh ${ }^{1 *}$, Le Tan Nghiem ${ }^{1}$, Nguyen Hong Gam², Pham Le Hong Nhung ${ }^{1}$ \\ ${ }^{1}$ Can Tho University, Vietnam \\ ${ }^{2}$ Nam Can Tho University, Vietnam \\ *Corresponding author: dcthanh@ctu.edu.vn
}

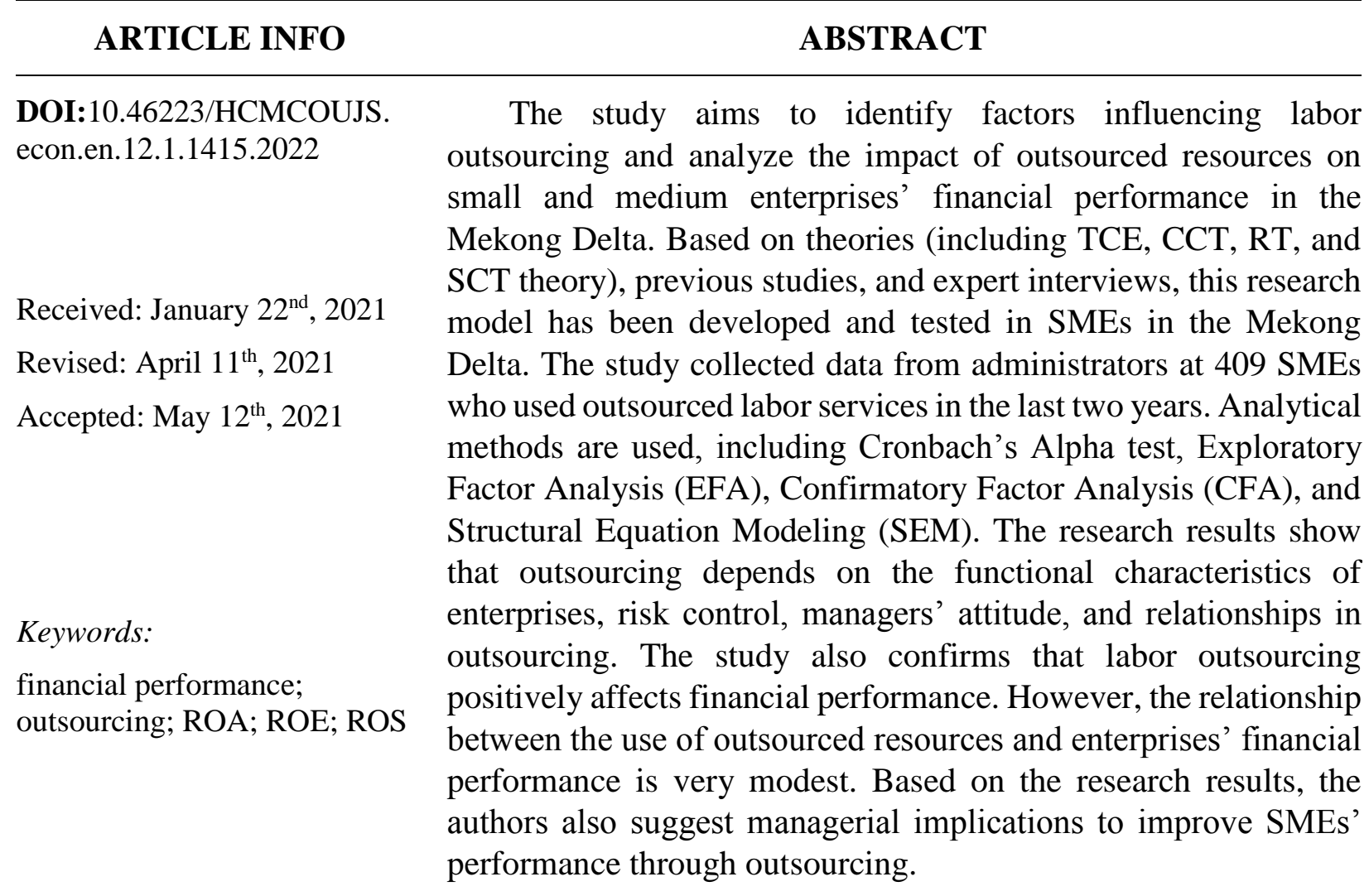

\section{Introduction}

Outsourcing is defined as the enterprise hiring resources provided by outside organizations/individuals through a contract signed between the parties (Yang, Kim, Nam, \& Min, 2007). Accordingly, outsourcing is a solution that can help enterprises reduce costs and streamline organizational structure. In particular, outsourcing helps managers focus more resources on essential activities in the enterprise. That is the reason why many enterprises around the world increasingly need to use outsourced services in recent years, especially Small and Medium Enterprises (SMEs). Enterprises outsource to solve difficulties such as lack of capital, human resources, and facilities (Anders \& Björn, 2015; Hafeez \& Andersen, 2014). When labor outsourcing, enterprises do not need to invest too much in recruitment. Thereby, it can help reduce the enterprise's cumbersome structure and significantly increase personnel's flexibility at different times (Assaf, Hassanain, Al- Hammad, \& Al- Nehmi, 2011).

In Vietnam, recognizing the importance of outsourcing, the Government has issued many policies related to outsourcing to support enterprises. Accordingly, in 2013, the Government (2013) issued Decree No. 55/2013/ND-CP regulating the outsourcing of 17 jobs. By 2019, 
Government (2019) has issued Decree No. 29/2019/ND-CP based on supplementing Decree No. 55 (Government, 2013) with 20 job lists in which enterprises are allowed to outsource labor. With the above benefits and opportunities, enterprises in Vietnam in general and SMEs in the Mekong Delta in particular are increasingly outsourcing labor (Dinh, Le, \& Nguyen, 2020).

However, enterprises using outsourced resources may also have problems. Zameer and Ali (2013) pointed out that outsourced enterprises may face some disadvantages. The most significant risk is the inability to control the activities of the service providers to the enterprise. Moreover, it isn't easy to keep the information confidential in enterprises. In some cases, service providers' employees may lack motivation, negatively affecting the enterprise's quality and progress (Gewald \& Dibbern, 2009; Zameer \& Ali, 2013).

Nowadays, there are many different debates about the impact of outsourcing on performance. Accordingly, most studies show that outsourcing positively affects enterprises' financial performance (Isaksson \& Lantz, 2015; Kamyabi \& Devi, 2011; Kroes \& Ghosh, 2010). However, there is also research that outsourcing does not improve and negatively affects financial performance (Anders \& Björn, 2015). In addition, there are also studies that outsourcing does not affect financial performance (Gilley, Greer, \& Rasheed, 2004). Thus, the questions are: (i) how has the situation of outsourcing SMEs in the Mekong Delta over the last time? (ii) Does outsourcing SMEs' labor have an impact on financial performance? (iii) What solutions should be proposed to improve SMEs' performance through labor outsourcing? For these reasons, research is conducted aimed at the goals: (i) Analyze the situation of labor outsourcing in SMEs in the Mekong Delta; (ii) Study the impact of using outsourced on the financial performance of the enterprise; (iii) On that basis, research proposes solutions to improve labor outsourcing efficiency in SMEs in the Mekong Delta.

\section{Theoretical framework and research model}

\subsection{Theoretical framework}

\subsubsection{The theoretical framework for outsourcing}

There is no unified theory of the origin of outsourcing (Agburu, Anza, \& Iyortsuun, 2017). Accordingly, scientists often rely on relevant theories to explain outsourcing activities. Many studies are based on the Transaction Cost Economics Theory (TCE) proposed by Coase (1995). According to TCE theory, cost savings are essential for any enterprise. This theory can explain that enterprises need to take advantage of opportunities from external organizations/individuals' resources to achieve cost-saving benefits. Indeed, Gewald and Dibbern (2009); Gewald (2010) have researched and pointed out that managers appreciate the outsourcing benefits that will positively impact outsourcing in enterprises. Based on TCE theory, Gewald and Dibbern (2009), Zameer and Ali (2013), Agburu et al. (2017) also pointed out that outsourcing labor in enterprises also has specific risks especially the risk of additional costs. This may negatively affect enterprise performance. Therefore, outsourcing labor also depends on the manager's attitude towards outsourcing activities in enterprises. Thus, TCE theory can be used to explain factors influencing outsourcing in SMEs in the Mekong Delta. According to this theory, outsourcing in enterprises can depend on three factors: (1) the perception of the benefits of outsourcing; (2) the risks of outsourcing; (3) managers' attitudes towards outsourcing. However, the research based on TCE theory are limited in identifying factors affecting outsourcing. Therefore, this study also relies on Core Competency Theory (CCT) to explain enterprises' outsourcing decisions.

Core Competency Theory (CCT) was developed by Prahalad and Hamel (1997). The CCT theory shows that any enterprise has individual strengths in internal resources that need to promote 
opportunities and improve enterprise performance. Hafeez and Andersen (2014) emphasized that outsourcing non-core activities are the best method to use resources effectively, especially SMEs. Therefore, the outsourcing decision depends on the functional characteristics of the enterprise. However, there are cases in which enterprises have all the necessary resources but continue to outsource, even outsource activities of core competencies, because outsourcing also depends on the company's strategy (Agburu et al., 2017). Kroes and Ghosh (2010) emphasized that the increase in outsourcing in enterprises depends on assessing this activity's suitability with the enterprise's business strategy. Thus, the Core Competency Theory can be applied to explain the SMEs' external resources in the Mekong Delta. Accordingly, the degree of outsourcing of enterprises may depend on factors: (i) outsourcing strategy of enterprises; (ii) the functional characteristics of the enterprise. However, the authors' studies based on CCT theory are also limited because they explain that outsourcing of enterprises only depends on functional characteristics and outsourcing strategy.

Also, this study is based on Relationship Theory (RT) proposed by Klepper (1995) and the Social Capital Theory (SCT) developed by Bourdieu (1986). The theory of RT and SCT emphasizes the necessity of factors creating relationships and cooperation of enterprises together. The results of this relationship and collaboration are beneficial for all parties. According to Agburu et al. (2017), some SMEs outsource to establish relationships with supply partners to benefit enterprises, not to minimize costs and seek profits. Thus, the RT and SCT theory can be applied to explain the impact of the relational factor on the use of resources provided by external organizations/individuals of SMEs in the Mekong Delta. Even so, Agburu et al. (2017) has not verified the influence of the relationship factor between parties on outsourcing by Agburu et al. (2017) has not collected data to substantiate their claims.

Thus, based on the above analysis shows, this study can apply TCE, CCT, RT, and SCT theory to explain SMEs' outsourcing decisions in the Mekong Delta. Accordingly, the outsourcing of enterprises depends on the following factors: (1) perceiving the benefits from the outsourcing; (2) risks of outsourcing; (3) characteristics of the internal resources of the enterprise; (4) the suitability of outsourcing activities with enterprise strategy; (5) managers' attitude towards outsourcing; (6) the relationship between the parties.

\subsubsection{The theoretical framework for performance}

Performance is a multi-dimensional concept. Depending on the context of enterprises' activities, research conditions, and objectives, the approaches to the theory of enterprise performance are different (Ondoro, 2015). According to Ondoro (2015), enterprise performance is the goal that every enterprise wants to achieve. This is an important category that many researchers in management are interested in exploiting. Therefore, many studies applied the Balanced Scorecard theory (BSC) of Kaplan and Norton (1992) to measure performance. According to BSC theory, the performance of an enterprise is usually assessed in four aspects: (i) financial performance; (ii) customer performance; (iii) performance of internal processes; and (iv) effectiveness in organizational innovation and development. Among those indicators, financial performance is considered a significant indicator to measure enterprises' performance (Kamyabi \& Devi, 2011; Kroes \& Ghosh, 2010). Accordingly, Brealey, Myers, and Marcus (2001) explained that many different indicators measure financial performance and enterprises' profitability. However, the most widely used and essential indicators to measure the performance of enterprises include: (1) Return On Assets (ROA); (2) Return On Equity (ROE); (3) and Return On Sales (ROS). Therefore, to test the impact of labor outsourcing on financial performance, the study uses 
ROA, ROE, and ROS criteria.

\subsection{Research model}

First, Gewald, and Dibbern (2009), Gewald (2010) affirmed that managers would have a positive attitude and increase outsourcing activities at enterprises when evaluating the benefits of this activity. Accordingly, using outsourced services can help enterprises save costs, and especially administrators can focus necessary resources on core activities. In addition, outsourcing also allows companies to share risks with suppliers. Therefore, the more managers appreciate these benefits, the more positive they are to outsourcing, and the more they will increase service usage. From the analysis, the research gives the following hypotheses:

\section{H1: There is a positive impact on the benefits of outsourcing on the level of outsourcing}

H2: There is a positive impact on the benefits of outsourcing on the attitude towards outsourcing

In addition to the benefits of outsourcing, this solution still has many potential risks for enterprises. Gewald and Dibbern (2009) point out that enterprises' risks are dependent on suppliers, challenging to control supplier activities. Moreover, enterprises may face the risk of work interruptions or rising costs. Enterprises may even be in danger of disclosing information and secrets from the outside. These are significant challenges for enterprises, especially SMEs (Agburu et al., 2017; Hafeez \& Andersen, 2014). Zameer and Ali (2013) argue that the nature of outsourcing always exists with risks. However, this does not limit the needs of enterprises to use services. Because outsourcing also depends on the ability of enterprises to control risks. Therefore, the authors propose the following hypotheses:

H3: There is a positive impact of control outsourcing risks on the level of outsourcing

H4: There is a positive impact of control outsourcing risks on the attitude towards outsourcing

Besides, there is a direct impact of the factors of benefits and risks on outsourcing in enterprises. Gewald and Dibbern (2009) also pointed out that the assessment of benefits and risks from outsourcing indirectly affects the outsourcing of enterprises through the intermediate variable, which is the outsourcing attitude of managers. Therefore, the study proposes hypothesis H5 as follows:

H5: There is a positive impact of the attitude towards outsourcing on the level of outsourcing

Another study by Kroes and Ghosh (2010) said that increasing the outsourcing level also depends on enterprises' outsourcing strategy. Because outsourcing decisions must be based on consistent with the goals and orientation of the enterprises' activities. From this argument, the study proposes the H6 hypothesis as follows:

H6: There is a positive impact of the strategy of the enterprise on the level of outsourcing

Moreover, Hafeez and Andersen (2014) also researched and confirmed that the above factors affect the level of outsourcing in enterprises, outsourcing also depends on many other factors, such as (i) frequency performance of works; (ii) human factor; and (iii) the size of the firm. Accordingly, enterprises with smaller operations tend to outsource more. Therefore, using resources from organizations/individuals depends on the enterprise's functional characteristics. Thus, the study proposes the hypothesis: 


\section{H7: There is a positive impact of organizational characteristics on the level of outsourcing}

From practice, the above studies are still limited in determining the factors that affect the degree of outsourcing compared to the theory because those authors used different background theories for their research. Therefore, the authors propose a general model of the impact of factors on outsourcing. In general, the level of outsourcing depends on factors: (1) perceived benefits, (2) ability to control risk, (3) attitude towards outsourcing, (4) the enterprises' strategy, and (5) functional characteristics. In addition, based on Relationship Theory (RT) and Social Capital Theory (SCT) combined with expert interviews. Based on qualitative research through expert interviews, it shows that outsourcing activities in the Mekong Delta depend on the relationship factors between stakeholders, mainly acquaintances. The result of this expert interview is consistent with RT and SCT theory. Besides, enterprises also take advantage of opportunities from outsourcing to build and develop long-term relationships with partners. Therefore, the study proposes to add the following hypothesis:

H8: There is a positive impact of relationships between stakeholders on the level of outsourcing

As mentioned above, many studies have proven that outsourcing impacts enterprises' performance, especially financial performance. Kamyabi and Devi (2011) argue that using external resources can help improve enterprises' profits, thanks to reducing costs. Thereby, it is possible to enhance the rate of Return On Assets (ROA). Besides, thanks to professional services from organizations/individuals, administrators can focus on all essential resources to serve customers. It can improve revenue and improve the profit margin on enterprises' sales ratio (ROS) (Kroes \& Ghosh, 2010). Not only that, but some authors also pointed out that service outsourcing also impacts the rate of return on equity of the enterprise (ROE) (Bustinza, Arias-Aranda, \& Gutierrez, 2010). From the analysis, the study expects the following hypothesis:

\section{H9: There is a positive impact on the level of outsourcing on financial performance}

Thus, based on summarizing theories, reviewing the related studies and expert interviews, the author proposes a model of the effect of labor outsourcing on the financial performance of SMEs in the Mekong Delta:

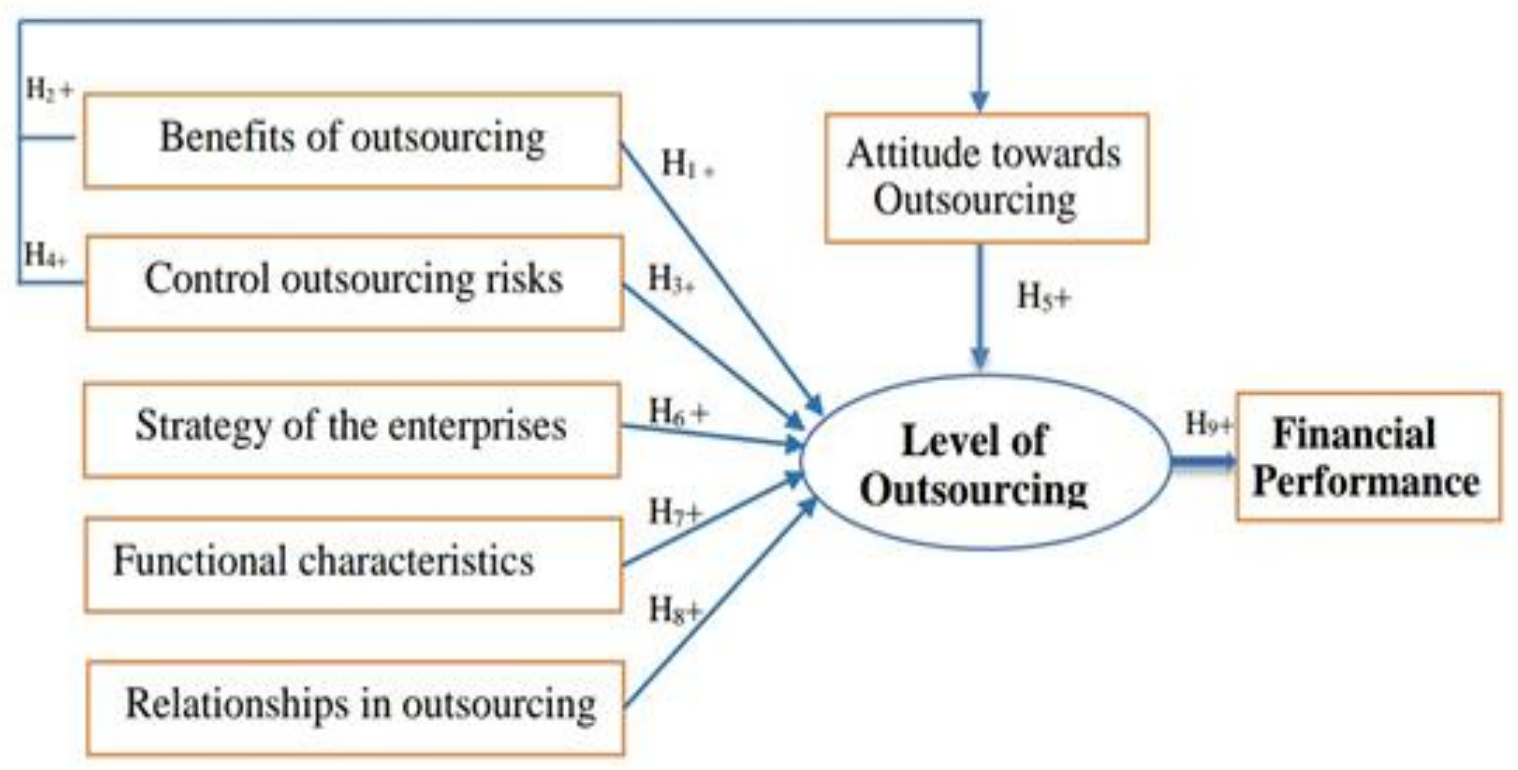

Figure 1. Model of the impact of labor outsourcing on the financial performance of SMEs in the Mekong Delta

Source: Author proposed 


\section{Table 1}

Describe the variables

\begin{tabular}{|c|c|c|}
\hline Variable & Observed variables & Citation \\
\hline \multicolumn{3}{|c|}{ I. Factors influencing the outsourcing } \\
\hline $\begin{array}{l}\text { 1. Benefits of } \\
\text { outsourcing } \\
(\mathrm{BEN})\end{array}$ & $\begin{array}{l}\text { 1. Saving of costs; } 2 \text {. Converting fixed costs into variable } \\
\text { costs; } 3 \text {. Focusing on performing core functions; } 4 \text {. Limit } \\
\text { the risks; } 5 \text {. Solving the problem of lack of labor; } 6 \text {. Sharing } \\
\text { part of the work is not important }\end{array}$ & $\begin{array}{l}\text { Gewald and Dibbern } \\
(2009) \text {; Gewald } \\
(2010) \text {; Interview the } \\
\text { experts }\end{array}$ \\
\hline $\begin{array}{l}\text { 2. Control } \\
\text { Outsourcing } \\
\text { Risks (ORM) }\end{array}$ & $\begin{array}{l}\text { 1. Depend on vendor; 2. Difficulty in controlling the } \\
\text { supplier; 3. Interrupting work; 4. Outsourcing costs are not } \\
\text { reduced; 5. Outsourcing costs increase; 6. Information } \\
\text { disclosure }\end{array}$ & $\begin{array}{l}\text { Gewald and Dibbern } \\
(2009) ; \text { Zameer and } \\
\text { Ali (2013) }\end{array}$ \\
\hline $\begin{array}{l}\text { 3. Functional } \\
\text { characteristics } \\
\text { (ORG) }\end{array}$ & $\begin{array}{l}\text { 1. Enterprises outsource less important works; } 2 \text {. Lack of } \\
\text { resources; } 3 \text {. The company's personnel cannot perform the } \\
\text { tasks well; } 4 \text {. Small enterprise size; } 5 \text {. There is a lot of work } \\
\text { to be solved }\end{array}$ & $\begin{array}{l}\text { Hafeez and } \\
(2014) ; \text { Int } \\
\text { experts }\end{array}$ \\
\hline $\begin{array}{l}\text { the enterprise } \\
\text { (STR) }\end{array}$ & $\begin{array}{l}\text { 1. Outsourcing is a common trend of enterprises; } 2 \text {. Increase } \\
\text { competitive advantages for enterprises; 3. Improve } \\
\text { products/services; } 4 \text {. Diversification strategy }\end{array}$ & $\begin{array}{l}\text { Kroes and Ghosh } \\
(2010)\end{array}$ \\
\hline $\begin{array}{l}\text { 5. Relationships } \\
\text { in outsourcing } \\
\text { (REL) }\end{array}$ & $\begin{array}{l}\text { 1. The enterprise has a close relationship with the supplier; } \\
\text { 2. The enterprise has built a long-term partnership; } 3 \text {. } \\
\text { Enterprises believe in the introduction of partners. }\end{array}$ & $\begin{array}{l}\text { tative } \\
\text { hS } \\
\text { NS }\end{array}$ \\
\hline $\begin{array}{l}\text { 6. Attitude } \\
\text { towards } \\
\text { outsourcing } \\
\text { (ATT) }\end{array}$ & $\begin{array}{l}\text { 1. The enterprise has a positive attitude towards } \\
\text { outsourcing; } 2 \text {. Outsourcing is suitable for enterprise goals; } \\
\text { 3. The benefits of outsourcing outweigh the risks; } 4 . \\
\text { Outsourcing is better; 5. The enterprise believes in } \\
\text { outsourcing activities }\end{array}$ & $\begin{array}{l}\text { Gewald and Dibbern } \\
(2009)\end{array}$ \\
\hline $\begin{array}{l}\text { II. Level of } \\
\text { outsourcing } \\
\text { (LVE) }\end{array}$ & $\begin{array}{l}\text { 1. Outsourcing rate of core activities; } 2 \text {. Outsourcing rate of } \\
\text { auxiliary activities; } 3 \text {. Annual cost ratio for outsourcing; } 4 \text {. } \\
\text { Enterprises will further strengthen outsourcing activities }\end{array}$ & $\begin{array}{l}\text { Gewald and Dibbern } \\
(2009) ; \text { Hafeez and } \\
\text { Andersen (2014) }\end{array}$ \\
\hline \multicolumn{3}{|c|}{ III. Financial performance } \\
\hline ROS & Return on net sales has grown over the years & \multirow{3}{*}{$\begin{array}{l}\text { Bustinza et al. } \\
(2010) \text {; Kamyabi and } \\
\text { Devi (2011); Kroes } \\
\text { and Ghosh (2010) }\end{array}$} \\
\hline ROE & Return on equity has grown over the years & \\
\hline ROA & Return on assets has grown over the years & \\
\hline
\end{tabular}

Source: References from related studies and expert interview

\section{Research methods}

\subsection{Data collection methods}

Primary data was collected from interviewing sixteen experts to develop and supplement the scale for the study. They are managers and staff in nine enterprises that outsource labor, and seven enterprises specialize in providing labor leasing services. Experts are those with practical experience in deciding to outsource and provide services to enterprises. The article uses semistructured interview to collect data.

In addition, this study also uses the non-probability sampling method with convenient sampling (mainly through acquaintances and referrals from the interviewed enterprises) to 
interview enterprises. The enterprises surveyed are SMEs using outsourced labor services in 06 provinces/cities of the Mekong Delta, including Can Tho City, Soc Trang, Bac Lieu, Tra Vinh, Vinh Long, and Dong Thap Province. Respondents are enterprise owners, directors/deputy directors, or heads/deputy heads of departments. The survey team (including 14 members) was trained in detail on the survey's content to collect data. In addition, there are $02-04$ members contacting enterprises to plan a direct interview and answer questionnaires in each research area. Data collection was conducted from January 2018 to April 2019. The total number of collected questionnaires was 425. However, there were 16 questionnaires with missing information and inappropriate answers. Therefore, the adequate number of observations used for this study is 409 .

\subsection{Analytical methods}

For expert interview data: the study uses a three-level coding method (Saldaña, 2015). Documented interview data will be coded sentence by sentence to determine codes. The codes are then considered for differences and similarities to be grouped into categories. Finally, the groups are analyzed to identify the research problem's theme/concept.

For interview data: the study uses analytical methods: (1) Cronbach's Alpha's test to test the reliability and evaluate the quality of the scale; (2) Exploratory Factor Analysis (EFA) to test the appropriateness of the scale; (3) Confirmatory Factor Analysis (CFA) to determine the suitability of research data with theoretical models; (4) Structural Equation Modeling (SEM) through AMOS software to test the relationship between concepts in the research model.

\section{Analytical results}

\subsection{The labor outsourcing situation of SMEs in the Mekong Delta}

Interview results of 409 SMEs in 06 provinces/cities in the Mekong Delta show the following information:

\section{Table 2}

Information about enterprises surveyed

\begin{tabular}{ccc}
\hline \multicolumn{1}{c}{ Items } & Number of surveys & Percent $(\%)$ \\
\hline Types of enterprise: & & \\
- Joint stock enterprise & 90 & 22.0 \\
- Limited enterprise & 230 & 56.2 \\
- Private & 84 & 20.6 \\
- Cooperative & 5 & 1.2 \\
\hline
\end{tabular}

Types of economic activity:

- Agriculture, forestry \& fishing

- Industry \& construction

- Trade \& service

Sizes of enterprise:

- Micro enterprises

- Small enterprises 
Survey results show that the enterprises that use outsourcing labor in the Mekong Delta are mostly limited and joint-stock enterprises, accounting for nearly $80 \%$ of enterprises surveyed. Most enterprises operate in trade - services (accounting for 51.6\%) and industry - construction (accounting for $35.7 \%$ ). This result shows that enterprises operating in these two fields have a high demand for labor outsourcing. Survey results also showed that most of the Mekong Delta enterprises are micro-enterprises (accounting for nearly 65\%), and small enterprises accounted for $32 \%$. Meanwhile, very few medium-sized enterprises use labor outsourcing, accounting for only $3.2 \%$ of enterprises surveyed.

In addition, research shows that the use of outsourced labor by SMEs in the Mekong Delta is quite diverse. Enterprises pay much attention to outsourcing accounting (accounting for $51.29 \%$ ), and professional security (accounting for $38.41 \%$ ). Details are as follows:

\section{Table 3}

Summary of services outsourced by SMEs in the Mekong Delta

\begin{tabular}{lcc}
\hline \multicolumn{1}{c}{ Types of outsourcing } & Number of surveys & Percent (\%) \\
\hline Accounting & 219 & 51.29 \\
Security & 164 & 38.41 \\
Labor supply and management & 158 & 37.00 \\
Cleaning & 114 & 26.70 \\
Machine maintenance & 109 & 25.53 \\
Marketing/customer care/sales support & 56 & 13.11 \\
Economic consulting and construction consulting & 49 & 11.48 \\
Training & 44 & 10.30 \\
Inventory & 31 & 7.26 \\
Management consulting, HR management & 30 & 7.03 \\
\hline
\end{tabular}

Source: Results of data processing from 409 enterprises

Also, services such as supply and management of labor resources, cleaning, and machine maintenance are used by many SMEs in the Mekong Delta (accounting for 37.0\%, 26.70\%, and $25.53 \%$, respectively). However, there are very few SMEs in the Mekong Delta interested in inventory services (accounting for 7.26\%) and management consulting and HR management (only $7.03 \%$ of enterprises).

\subsection{Model of the impact of labor outsourcing on the financial performance of SMEs in the Mekong Delta}

\subsubsection{Testing the reliability of the scales}

The study uses Cronbach's Alpha analysis to test the reliability and evaluate the quality of the scales. According to Hair, Black, Babin, Anderson, and Tatham (2014), the scale has good reliability if the Cronbach's Alpha coefficient is more significant than 0.60 , and the item-total correlation of variables is higher than 0.3 .

However, variables include BEN1, BEN2, and BEN4, which measure enterprises' perception of outsourcing benefits; variable ORM4 measures the ability to control the risk; ORG3 
and ORG4 measure the characteristics of the organization; the variable ATT5, which measures the concept of outsourcing's attitude that has corrected item-total correlation is less than 0.3. Therefore, these variables are excluded from the research model (Hair et al., 2014). The second Cronbach's Alpha test result for the following table:

\section{Table 4}

The results of testing the reliability of the scales

\begin{tabular}{lclc}
\hline \multicolumn{1}{c}{ Variable name } & $\begin{array}{c}\text { Number } \\
\text { of items }\end{array}$ & \multicolumn{1}{c}{ Variable } & $\begin{array}{c}\text { Cronbach's } \\
\text { Alpha }\end{array}$ \\
\hline 1. Benefits of outsourcing & 3 & BEN3, BEN5, BEN6 & 0.849 \\
2. Control outsourcing risks & 5 & ORM1, ORM2, ORM3, ORM5, ORM6 & 0.870 \\
3. Functional characteristics & 3 & ORG1, ORG2, ORG5 & 0.836 \\
4. Strategy of the enterprise & 4 & STR1, STR2, STR3, STR4 & 0.733 \\
5. Relationships in & 3 & REL1, REL2, REL3 & 0.728 \\
outsourcing & 4 & ATT1, ATT2, ATT3, ATT4 & 0.867 \\
\hline $\begin{array}{l}\text { 6. Attitude towards } \\
\text { outsourcing }\end{array}$ & 4 & LVE1, LVE2, LVE3, LVE4 & 0.838 \\
7. Level of outsourcing & 3 & ROA, ROS, ROE & 0.877 \\
8. Financial performance & &
\end{tabular}

Source: Results of data processing from 409 enterprises

\subsubsection{Exploratory Factor Analysis (EFA)}

The results of EFA analysis of the concept of factors affecting the level of labor outsourcing of SMEs in the Mekong Delta showed that the KMO coefficient reached 0.783 (satisfying the condition $0.50<\mathrm{KMO}<1)$, Barlett test with Sig. is $0.000(<0.005)$. The Eigenvalue index $>1$ shows that scales of concepts are grouped into five factors. The EFA results are summarized as follows:

\section{Table 5}

EFA analysis results of scale factors affecting the level of labor outsourcing

\begin{tabular}{|c|c|c|c|c|c|}
\hline Variable & $\begin{array}{l}\text { Outsourcing } \\
\text { risks }\end{array}$ & $\begin{array}{l}\text { Outsourcing } \\
\text { benefits }\end{array}$ & $\begin{array}{c}\text { Functional } \\
\text { characteristics }\end{array}$ & $\begin{array}{l}\text { The strategy of } \\
\text { the enterprise }\end{array}$ & $\begin{array}{c}\text { Relationships in } \\
\text { outsourcing }\end{array}$ \\
\hline \multicolumn{6}{|c|}{ Factor loadings } \\
\hline ORM1 & 0.900 & & & & \\
\hline ORM2 & 0.813 & & & & \\
\hline ORM3 & 0.770 & & & & \\
\hline ORM6 & 0.668 & & & & \\
\hline ORM5 & 0.645 & & & & \\
\hline BEN6 & & 0.904 & & & \\
\hline BEN3 & & 0.792 & & & \\
\hline
\end{tabular}




\begin{tabular}{|c|c|c|c|c|c|}
\hline Variable & $\begin{array}{l}\text { Outsourcing } \\
\text { risks }\end{array}$ & $\begin{array}{l}\text { Outsourcing } \\
\text { benefits }\end{array}$ & $\begin{array}{c}\text { Functional } \\
\text { characteristics }\end{array}$ & $\begin{array}{l}\text { The strategy of } \\
\text { the enterprise }\end{array}$ & $\begin{array}{l}\text { Relationships in } \\
\text { outsourcing }\end{array}$ \\
\hline BEN5 & & 0.736 & & & \\
\hline ORG2 & & & 0.829 & & \\
\hline ORG5 & & & 0.785 & & \\
\hline ORG1 & & & 0.771 & & \\
\hline STR4 & & & & 0.734 & \\
\hline STR2 & & & & 0.682 & \\
\hline STR3 & & & & 0.614 & \\
\hline STR1 & & & & 0.532 & \\
\hline REL2 & & & & & 0.786 \\
\hline REL1 & & & & & 0.714 \\
\hline REL3 & & & & & 0.572 \\
\hline
\end{tabular}

$K M O=0.783 ;$ Sig. $=0.000 ;$ Eigenvalue $=1.537>1 ;$ Total Variance Explained $=55.70 \%$

Source: Results of data processing from 409 enterprises

Next, the study will analyze the EFA for concepts such as attitudes towards outsourcing, outsourcing level, and SMEs' financial performance in the Mekong Delta. EFA analysis results are shown in the following table:

\section{Table 6}

EFA for the scale of attitude, level of outsourcing and financial performance

\begin{tabular}{lccccc}
\hline \multicolumn{1}{c}{ Variable name } & KMO & $\begin{array}{c}\text { Bartlett's } \\
\text { test }\end{array}$ & $\begin{array}{c}\text { Total variance } \\
\text { explained (\%) }\end{array}$ & Eigenvalue & $\begin{array}{c}\text { Number of } \\
\text { groups }\end{array}$ \\
\hline Attitude towards outsourcing & 0.804 & 0.000 & 71.70 & 2.868 & 1 \\
Level of outsourcing & 0.756 & 0.000 & 67.97 & 2.719 & 1 \\
Financial performance & 0.716 & 0.000 & 80.25 & 2.407 & 1 \\
\hline
\end{tabular}

Source: Results of data processing from 409 enterprises

The results of the EFA analysis (in Table 6) the scales of labor outsourcing attitude, the level of outsourcing, and financial performance also showed that the KMO coefficient satisfies the condition $0.50<\mathrm{KMO}<1$, the total variance of explaining the concepts is high more than $50 \%$, Bartlett's test with Sig is 0.000 (satisfying the condition <0.005). Therefore, the model is perfectly suitable for market data (Hair et al., 2014). So the study continues to analyze the Confirmatory Factor Analysis (CFA).

\subsubsection{Confirmatory Factor Analysis}

According to Nguyen and Nguyen (2008), the research model is considered appropriate when the indicators include TLI, CFI $\geq 0.9 ; \mathrm{CMIN} / \mathrm{df} \leq 2 ; \mathrm{RMSEA} \leq 0.08$. The results of the CFA saturated model showed that the Chi-square test had $\mathrm{P}=0.000$. Indicators such as $\mathrm{CMIN} / \mathrm{df}=$ $1.613 \leq 2 ; \mathrm{TLI}=0.954, \mathrm{CFI}=0.961 \geq 0.9$, and $\mathrm{RMSEA}=0.039 \leq 0.08$ show that the model is consistent the market data. The results in the saturated model are shown in the following figure: 


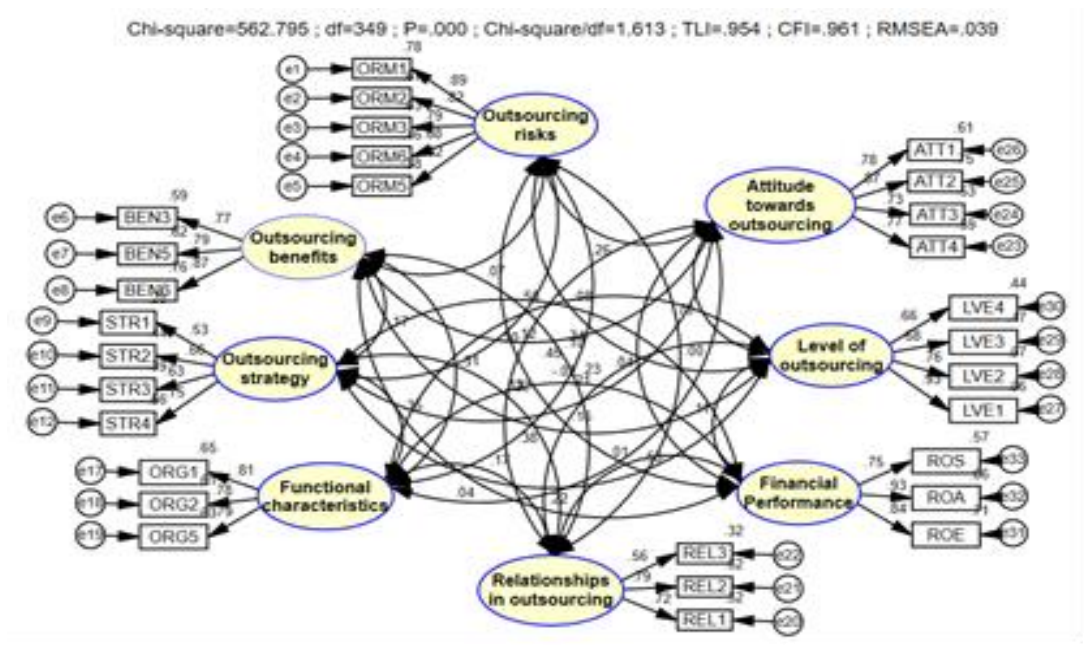

Figure 2. Saturated model (standardised parameters)

Source: Results of data processing from 409 enterprises

CFA analysis results of the saturated model in Figure 2 show that all variables' CFA standardized weights are greater than 0.5 (the lowest is 0.530). Therefore, scales ensure unidimensional constructs and convergent validity (Nguyen \& Nguyen, 2008). The authors continue to test the discriminant validity of the scales. The test results are shown in the following table:

\section{Table 7}

The results of the unidimensional constructs test

\begin{tabular}{|l|l|l|r|c|c|c|}
\hline \multicolumn{2}{|c|}{ Relationship } & Estimate & S.E & C.R & P \\
\hline The strategy of the enterprise & $\leftrightarrow$ & Benefits of outsourcing & 0.167 & 0.049 & 17.045 & 0.000 \\
\hline Level of outsourcing & $\leftrightarrow$ & Financial performance & 0.106 & 0.049 & 18.138 & 0.000 \\
\hline Relationships in outsourcing & $\leftrightarrow$ & Financial performance & 0.014 & 0.050 & 19.894 & 0.000 \\
\hline The strategy of the enterprise & $\leftrightarrow$ & Functional characteristics & 0.348 & 0.046 & 14.031 & 0.000 \\
\hline Benefits of outsourcing & $\leftrightarrow$ & Functional characteristics & 0.307 & 0.047 & 14.690 & 0.000 \\
\hline Functional characteristics & $\leftrightarrow$ & $\begin{array}{l}\text { Relationships in } \\
\text { outsourcing }\end{array}$ & 0.173 & 0.049 & 16.940 & 0.000 \\
\hline Attitude towards outsourcing & $\leftrightarrow$ & Level of outsourcing & 0.699 & 0.035 & 8.491 & 0.000 \\
\hline Control outsourcing risks & $\leftrightarrow$ & Benefits of outsourcing & 0.069 & 0.049 & 18.827 & 0.000 \\
\hline Control outsourcing risks & $\leftrightarrow$ & $\begin{array}{l}\text { Attitude towards } \\
\text { outsourcing }\end{array}$ & 0.262 & 0.048 & 15.428 & 0.000 \\
\hline Control outsourcing risks & $\leftrightarrow$ & Level of outsourcing & 0.338 & 0.047 & 14.191 & 0.000 \\
\hline Control outsourcing risks & $\leftrightarrow$ & Strategy of the enterprise & 0.122 & 0.049 & 17.846 & 0.000 \\
\hline Attitude towards outsourcing & $\leftrightarrow$ & Financial performance & 0.044 & 0.050 & 19.305 & 0.000 \\
\hline Benefits of outsourcing & $\leftrightarrow$ & $\begin{array}{l}\text { Attitude towards } \\
\text { outsourcing }\end{array}$ & 0.447 & 0.044 & 12.472 & 0.000 \\
\hline Benefits of outsourcing & $\leftrightarrow$ & Level of outsourcing & 0.376 & 0.046 & 13.586 & 0.000 \\
\hline The strategy of the enterprise & $\leftrightarrow$ & $\begin{array}{l}\text { Attitude towards } \\
\text { outsourcing }\end{array}$ & 0.165 & 0.049 & 17.080 & 0.000 \\
\hline
\end{tabular}




\begin{tabular}{|c|c|c|c|c|c|c|}
\hline \multicolumn{3}{|c|}{ Relationship } & \multirow{2}{*}{\begin{tabular}{|c|} 
Estimate \\
0.224
\end{tabular}} & \multirow{2}{*}{\begin{tabular}{|c|} 
S.E \\
0.048
\end{tabular}} & \multirow{2}{*}{\begin{tabular}{|c|} 
C.R \\
16.063
\end{tabular}} & \multirow{2}{*}{\begin{tabular}{c|}
$\mathbf{P}$ \\
0.000
\end{tabular}} \\
\hline The strategy of the enterprise & $\leftrightarrow$ & Level of outsourcing & & & & \\
\hline Control outsourcing risks & $\leftrightarrow$ & Functional characteristics & 0.226 & 0.048 & 16.030 & 0.000 \\
\hline Functional characteristics & $\leftrightarrow$ & $\begin{array}{l}\text { Attitude towards } \\
\text { outsourcing }\end{array}$ & 0.527 & 0.042 & 11.228 & 0.000 \\
\hline Functional characteristics & $\leftrightarrow$ & Level of outsourcing & 0.581 & 0.040 & 10.386 & 0.000 \\
\hline Relationships in outsourcing & $\leftrightarrow$ & Level of outsourcing & 0.207 & 0.048 & 16.352 & 0.000 \\
\hline Relationships in outsourcing & $\leftrightarrow$ & $\begin{array}{l}\text { Attitude towards } \\
\text { outsourcing }\end{array}$ & 0.099 & 0.049 & 18.267 & 0.000 \\
\hline The strategy of the enterprise & $\leftrightarrow$ & $\begin{array}{l}\text { Relationships in } \\
\text { outsourcing }\end{array}$ & 0.225 & 0.048 & 16.046 & 0.000 \\
\hline Benefits of outsourcing & $\leftrightarrow$ & $\begin{array}{l}\text { Relationships in } \\
\text { outsourcing }\end{array}$ & 0.103 & 0.049 & 18.193 & 0.000 \\
\hline Control outsourcing risks & $\leftrightarrow$ & $\begin{array}{l}\text { Relationships in } \\
\text { outsourcing }\end{array}$ & -0.004 & 0.050 & 20.255 & 0.000 \\
\hline Functional characteristics & $\leftrightarrow$ & Financial performance & -0.025 & 0.050 & 20.685 & 0.000 \\
\hline The strategy of the enterprise & $\leftrightarrow$ & Financial performance & 0.075 & 0.049 & 18.714 & 0.000 \\
\hline Control outsourcing risks & $\leftrightarrow$ & Financial performance & 0.126 & 0.049 & 17.774 & 0.000 \\
\hline Benefits of outsourcing & $\leftrightarrow$ & Financial performance & 0.036 & 0.050 & 19.461 & 0.000 \\
\hline
\end{tabular}

Source: Results of data processing from 409 enterprises

The discriminant validity test results in Table 7 show that the P-value of the concepts is all less than 0.05 , so the correlation coefficient of each pair of concepts is less than 1 at $95 \%$ confidence. Consequently, the research model scales are discriminant validity (Nguyen \& Nguyen, 2008).

In addition, according to Hair et al. (2014), to ensure the scale's reliability, the composite reliability, and the total variance extracted must have a value of 0.5 or more. However, the total extracted variance can still accept values from 0.4 but must ensure the overall reliability of greater than 0.6 (Fornell \& Larcker, 1981). The summary results are shown in Table 8:

\section{Table 8}

Summary results of testing the reliability

\begin{tabular}{lcccc}
\hline \multicolumn{1}{c}{ Variable name } & $\begin{array}{c}\text { Number } \\
\text { of items }\end{array}$ & $\begin{array}{c}\text { Composite } \\
\text { reliability }\end{array}$ & $\begin{array}{c}\text { Total variance } \\
\text { explained }\end{array}$ & Conclusion \\
\hline 1. Factors influencing the labor outsourcing & & & \\
\hline - Benefits of outsourcing & 3 & 0.851 & 0657 \\
- Control outsourcing risks & 5 & 0.874 & 0.585 \\
- Functional characteristics & 3 & 0.836 & 0.629 & \multirow{2}{*}{ Reliable } \\
- Strategy of the enterprise & 4 & 0.737 & 0.416 & \\
- Relationships in outsourcing & 3 & 0.736 & 0.486 & \\
\hline - Attitude towards outsourcing & 4 & 0.868 & 0.623 & \\
\hline 2. Level of outsourcing & 4 & 0.846 & 0.583 & \\
\hline 3. Financial performance & 3 & 0.880 & 0.711 &
\end{tabular}

Source: Results of data processing from 409 enterprises 
Thus, the analytical results in Table 8 show that all the research model concepts meet the requirement of high reliability. Therefore, the scale is suitable for analyzing the structural equation analysis (SEM).

\subsubsection{Test theoretical model by SEM}

To test the hypotheses, the author analyzes the structural equation analysis. Analytical results show that the model with Chi-square is 726.785 with $\mathrm{P}=0.000$. The indicators $\mathrm{CMIN} / \mathrm{df}=$ $1.975<2$; $\mathrm{TLI}=0.927>0.9 ; \mathrm{CFI}=0.934>0.9$, and $\mathrm{RMSEA}=0.049<0.08$ meet the analysis requirements. This shows that the model is well suited to market data. The research has found the relationship between the concepts in the model, as shown in the following figure:

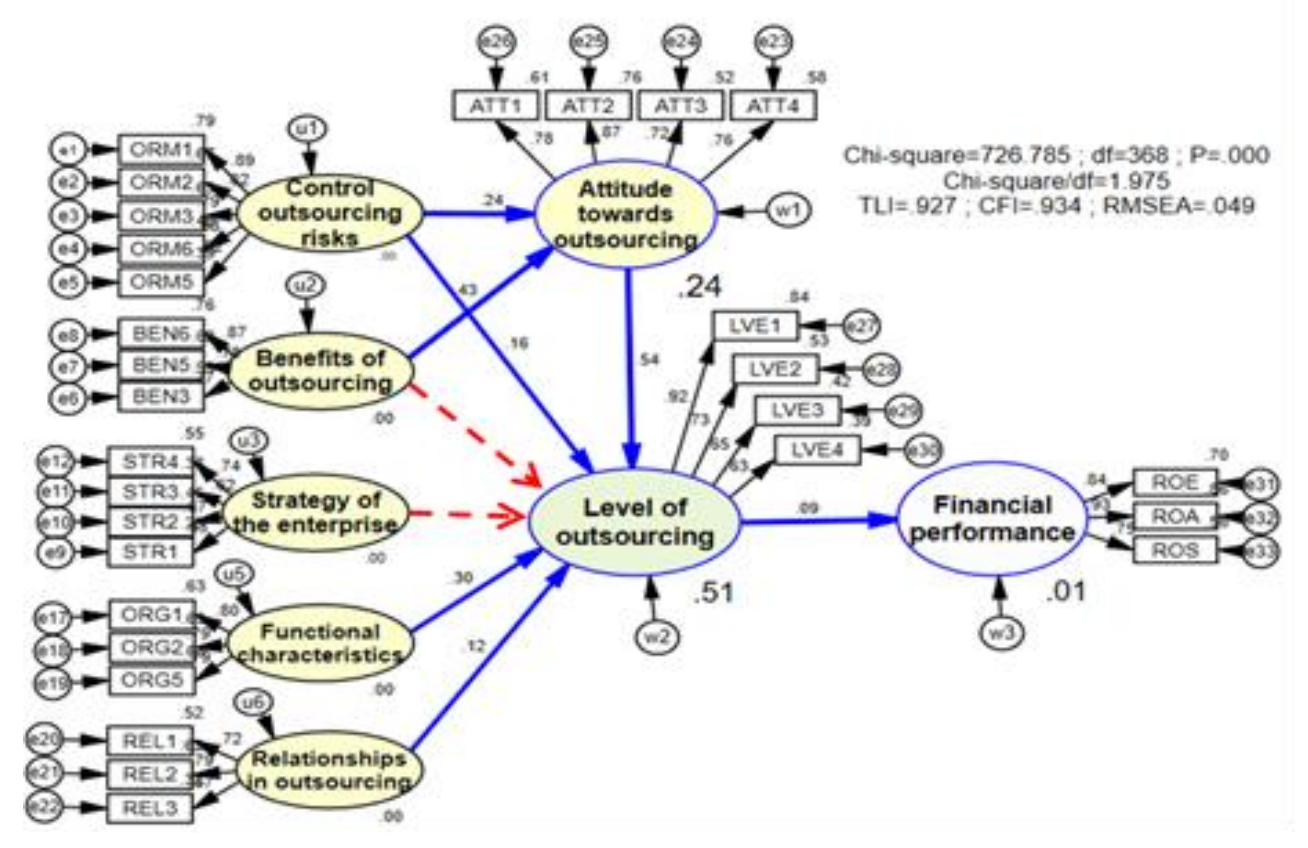

Figure 3. SEM analysis results

Note: $\longrightarrow$ : Shows the impact at the statistical significance level of $10 \%$

$-\rightarrow$ : Shows no impact at the statistical significance level of $10 \%$

Source: Results of data processing from 409 enterprises

The results in Figure 3 show that, at $90 \%$ confidence, the results are similar to previous authors' studies that SMEs' labor outsourcing in the Mekong Delta depends on the elements: (1) The ability to control risks, a factor that directly and indirectly affects the outsourcing of enterprises through managers' outsourcing attitude (Table 9 and Table 10); (2) The manager's attitude toward outsourcing; (3) Functional characteristics of organizations; and (4) Relationships among related parties. In which the attitude factor has the strongest impact on the level of labor outsourcing. The research results in Figures 3 and Table 9 also show that labor outsourcing in SMEs in the Mekong Delta impacts financial performance. However, the correlation between outsourcing and financial performance is very modest $\left(\mathrm{R}^{2}=0.9 \%\right)$. Isaksson and Lantz (2015) explain that business performance depends on many different factors, while outsourcing has a meager impact on enterprises' financial performance. Details are as follows: 


\section{Table 9}

SEM the results test the relationship between the concepts in the model

\begin{tabular}{|c|c|c|c|c|c|}
\hline \multicolumn{3}{|c|}{ Relationships } & Estimate & $\mathbf{P}$ & Result \\
\hline Benefits of outsourcing & $\rightarrow$ & Attitude towards outsourcing & 0.431 & 0.000 & Supported \\
\hline Control outsourcing risks & $\rightarrow$ & Attitude towards outsourcing & 0.240 & 0.000 & Supported \\
\hline Attitude towards outsourcing & $\rightarrow$ & Level of outsourcing & 0.544 & 0.000 & Supported \\
\hline The strategy of the enterprise & $\rightarrow$ & Level of outsourcing & 0.025 & 0.591 & Not supported \\
\hline Control outsourcing risks & $\rightarrow$ & Level of outsourcing & 0.163 & 0.000 & Supported \\
\hline Benefits of outsourcing & $\rightarrow$ & Level of outsourcing & 0.069 & 0.177 & Not supported \\
\hline Functional characteristics & $\rightarrow$ & Level of outsourcing & 0.297 & 0.000 & Supported \\
\hline Relationships in outsourcing & $\rightarrow$ & Level of outsourcing & 0.123 & 0.010 & Supported \\
\hline Level of outsourcing & $\rightarrow$ & Financial performance & 0.094 & 0.088 & Supported \\
\hline
\end{tabular}

Source: Results of data processing from 409 enterprises

However, the study has no evidence to prove the impact of the perceived benefit factor from labor outsourcing to the outsourcing level of enterprises like Gewald and Dibbern (2009), and Gewald (2010). The reason may be that SMEs in the Mekong Delta are not fully aware of outsourcing's benefits. Meanwhile, the benefit factor impacts the level of outsourcing through the managers' attitude towards outsourcing. Because Gewald and Dibbern (2009) argue that, in addition to the direct impact, the perceived benefits and risks also indirectly affect the outsourcing level through managers' attitudes towards outsourcing. The test results are shown in the following table:

\section{Table 10}

Analysis of direct and indirect effects of the scales

\begin{tabular}{|c|c|c|c|c|c|c|}
\hline \multicolumn{3}{|c|}{ Relationships } & Effects & Estimates & C.R & $\mathbf{P}$ \\
\hline \multirow{2}{*}{$\begin{array}{l}\text { Control } \\
\text { outsourcing } \\
\text { risks }\end{array}$} & \multirow[b]{2}{*}{$\rightarrow$} & \multirow{2}{*}{$\begin{array}{c}\text { Level of } \\
\text { outsourcing }\end{array}$} & Direct & 0.163 & 3.562 & 0.000 \\
\hline & & & $\begin{array}{l}\text { Indirect (through Attitude to } \\
\text { outsourcing) }\end{array}$ & 0.131 & 4.168 & 0.000 \\
\hline \multirow{2}{*}{$\begin{array}{l}\text { Benefits of } \\
\text { outsourcing }\end{array}$} & \multirow[b]{2}{*}{$\rightarrow$} & \multirow{2}{*}{$\begin{array}{c}\text { Level of } \\
\text { outsourcing }\end{array}$} & Direct & 0.069 & 1.349 & 0.177 \\
\hline & & & $\begin{array}{l}\text { Indirect (through Attitude to } \\
\text { outsourcing) }\end{array}$ & 0.235 & 5.882 & 0.000 \\
\hline
\end{tabular}

Source: Results of data processing from 409 enterprises

In addition, this study has not demonstrated the impact of the firm's strategic factors on the use of outsourced resources, as research by Kroes and Ghosh (2010). This can be explained that SMEs in the Mekong Delta have not had a long-term labor outsourcing strategy. Accordingly, enterprises outsource labor services mainly to solve difficulties due to a lack of resources in the short term.

\section{Conclusions and managerial implications}

\subsection{Conclusions}

The research results show that labor outsourcing of SMEs in the Mekong Delta is quite 
diverse. The most common are accounting, security, labor supply and management, and cleaning services. Because outsourcing these services can help enterprises solve difficulties due to lack of resources, save costs, and take advantage of professionalism. In addition, administrators can focus all resources on performing core activities in the organization. However, the labor outsourcing of SMEs in the Mekong Delta is hidden many risks. The biggest challenge is the risk of losing control due to dependence on supplier partners. This can negatively affect the progress and quality of work, possibly even increasing the enterprise's costs. Moreover, the risk of disclosing confidentiality and information in enterprises is also a problem that enterprises in the Mekong Delta also encounter when using outsourced services. Therefore, enterprises need solutions to limit risks when using services provided by external organizations and individuals.

The research results also show that outsourcing of SMEs in the Mekong Delta depends on the ability to control outsourcing risks, enterprises' functional characteristics, and the relationship in outsourcing. Also, the level of using outsourced resources of enterprises depends on administrators' attitude towards this activity, which is the most influential factor in outsourcing enterprises.

The research results also prove that labor outsourcing in SMEs in the Mekong Delta has a positive impact on the enterprises' financial performance. Accordingly, the labor outsourcing solution affects the rate of Return On Sales (ROS), Return On Assets (ROA), and Return On Equity (ROE). However, the correlation between outsourcing and financial performance is modest, with only $0.9 \%$ explanation.

\subsection{Managerial implications}

The research results show that, although outsourcing brings efficiency to enterprises, there are many potential risks. Therefore, enterprises need to strengthen the supplier's control activities to ensure the plan and work quality. The outsourcing contract should have strict conditions, specifying responsibilities and obligations between the parties to minimize the supplier's dependence. Enterprises also need to provide rules on progress reporting. Moreover, the supplier needs to commit to protecting the business information's confidentiality, avoiding disclosing the enterprise's information. When deciding to outsource, enterprises should fully estimate expenses to prevent additional costs incurred outside the contract.

In addition, the research results also show that the functional characteristics of enterprises affect outsourcing. Therefore, it is necessary to evaluate activities and work in enterprises carefully. Accordingly, businesses should only outsource activities/functions that are not important, and thereby administrators will focus the necessary resources for core activities.

The study also shows that businesses outsourcing depends on the relationships between stakeholders. Therefore, companies also need to establish relationships with suppliers to improve efficiency in using outsourced resources. Then, administrators will feel more secure when transferring a part of the enterprise's work to the service provider for implementation.

Limitations of the study and suggestions for future research: First, the study only focuses on analyzing the impact of labor outsourcing on SMEs' performance, so there is no comparison of outsourcing efficiency between SMEs and larger enterprises. Second, this study's performance scale is based on respondents' perceptions and assessments through the Likert scale due to the enterprise's information security requirements. Therefore, future studies can consider expanding the scope to include large-scale enterprises to compare the outsourcing efficiency according to each size of enterprises. 


\section{References}

Agburu, J. I., Anza, N. C., \& Iyortsuun, A. S. (2017). Effect of outsourcing strategies on the performance of Small and Medium scale enterprises (SMEs). Journal of Global Entrepreneurship Research, 7(1), Article 26. doi:10.1186/s40497-017-0084-0

Anders, I., \& Björn, L. (2015). Outsourcing strategies and their impact on financial performance in small manufacturing firms in Sweden. International Journal of Business and Finance Research, 9(4), 11-20.

Assaf, S., Hassanain, M. A., Al- Hammad, A. M., \& Al- Nehmi, A. (2011). Factors affecting outsourcing decisions of maintenance services in Saudi Arabian universities. Property Management, 29(2), 195-212. doi:10.1108/02637471111122471

Bourdieu, P. (1986). The forms of capital. In J. G. Richardson (Ed.), Handbook of theory and research for the sociology of education (pp. 241-258). New York, NY: Greenwood.

Brealey, R. A., Myers, S. C., \& Marcus, A. J. (2001). Fundamentals of corporate finance (3rd ed.). New York, NY: McGraw-Hill.

Bustinza, O. F., Arias-Aranda, D., \& Gutierrez, L. (2010). Outsourcing, competitive capabilities and performance: An empirical study in service firms. International Journal of Production Economics, 126(2), 276-288. doi:10.1016/j.ijpe.2010.03.023

Coase, R. H. (1995). The nature of the firm. In Essential readings in economics (pp. 37-54). London, UK: Palgrave.

Dinh, T. C., Le, N. T., \& Nguyen, G. H. (2020). The effect of outsourcing on the non-financial performance of SMES in the Mekong Delta. Journal of Trade Science, 8(1), 62-72.

Fornell, C., \& Larcker, D. F. (1981). Evaluating structural equation models with unobservable. Journal of Marketing Research, 18(1), 39-50. doi:10.1177/002224378101800104

Gewald, H. (2010). The perceived benefits of business process outsourcing: An empirical study of the German banking industry. Strategic Outsourcing: An International Journal, 3(2), 89105. doi:10.1108/17538291011060321

Gewald, H., \& Dibbern, J. (2009). Risks and benefits of business process outsourcing: A study of transaction services in the German banking industry. Information \& Management, 46(4), 249-257. doi:10.1016/j.im.2009.03.002

Gilley, K. M., Greer, C. R., \& Rasheed, A. A. (2004). Human resource outsourcing and organizational performance in manufacturing firms. Journal of Business Research, 57(3), 232-240. doi:10.1016/S0148-2963(02)00304-1

Government. (2013). Decree No. 55/2013/ND-CP - Detailing the implementation of Clause 3, Article 54 of the labor code on license for the outsourcing services, payment of deposits, and list of jobs entitled to carry out outsourcing. Retrieved May 22, 2013, from https://vanbanphapluat.co/decree-no-55-2013-nd-cp-detailing-the-implementation-ofclause-3-article-54

Government. (2019). Decree No. 29/2019/ND-CP - Detailing the implementation of Clause 3, Article 54 of the labor code regarding the licensing of the outsourcing operation, deposit payment, and list of permissible outsourced jobs. Retrieved March 20, 2019, from https://thukyluat.vn/vb/decree-29-2019-nd-cp-guidelines-clause-3-article-54-labor-codeon-deposit-payment-64711.html?hl=en 
Hafeez, A., \& Andersen, O. (2014). Factors influencing accounting outsourcing practices among SMEs in Pakistan context: Transaction Cost Economics (TCE) and Resource-Based Views (RBV) prospective. International Journal of Business and Management, 9(7), 19-32. doi:10.5539/ijbm.v9n7p19

Hair, J. F., Black, W. C., Babin, B. J., Anderson, R. E., \& Tatham, R. L. (2014). Multivariate data analysis (6th ed.). Cranbury, NJ: Pearson Education.

Isaksson, A., \& Lantz, B. (2015). Outsourcing strategies and their impact on financial performance in small manufacturing firms in Sweden. The International Journal of Business and Finance Research, 9(4), 11-20.

Kamyabi, Y., \& Devi, S. (2011). Accounting outsourcing and firm performance in Iranian SMEs. International Journal of Economics and Finance, 3(4), 181-192. doi:10.5539/ijef.v3n4p181

Kaplan, R. S., \& Norton, D. P. (1992). In search of excellence - der Maßstab muß neu definiert warden [In search of excellence - The standard has to be redefined]. Harvard Manager, 14(4), 37-46.

Klepper, R. (1995). The management of partnering development in IS outsourcing. Journal of Information Technology, 10(4), 248-258. doi:10.1177/026839629501000405

Kroes, J. R., \& Ghosh, S. (2010). Outsourcing congruence with competitive priorities: Impact on supply chain and firm performance. Journal of Operations Management, 28, 124-143. doi:10.1016/j.jom.2009.09.004

Nguyen, T. D., \& Nguyen, T. T. M. (2008). Nghiên cúu khoa học marketing - Úng dụng mô hình cấu trúc tuyến tính SEM [Marketing science research - Application of SEM linear structure modeling]. Ho Chi Minh City, Vietnam: National University Publishing House.

Ondoro, C. O. (2015). Measuring organization performance from balanced scorecard to balanced ESG framework. International Journal of Economics, Commerce and Management, 11(3), 715-725.

Prahalad, C. K., \& Hamel, G. (1997). The core competence of the corporation. In D. Hahn \& B. Taylor (Eds.), Strategische unternehmungsplanung/Strategische unternehmungsführung. Heidelberg, Germany: Physica.

Saldaña, J. (2015). The coding manual for qualitative researchers (3rd ed.). London, UK: Sage Publications Ltd.

Yang, D. H., Kim, S., Nam, C., \& Min, J. W. (2007). Developing a decision model for business process outsourcing. Computers \& Operations Research, 34(12), 3769-3778. doi:10.1016/j.cor.2006.01.012

Zameer, A., \& Ali, F. (2013). Factors influencing the outsourcing decisions: A study of the banking sector in Pakistan. International Journal of Operation, 2(3), 1-13.

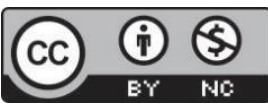

Creative Commons Attribution-NonCommercial 4.0 International License. 